\title{
Body image during sexual activity in the population of Polish adult women
}

\author{
Krzysztof Nowosielski ${ }^{1}$, Jacek Kurpisz ${ }^{2}$, Robert Kowalczyk ${ }^{3}$ \\ ${ }^{1}$ Department of Physiotherapy, Medical School in Opole, Opole, Poland \\ 2Department and Clinic of Psychiatry, Pomeranian Medical University, Szczecin, Poland \\ ${ }^{3}$ Department of Sexology, Andrzej Frycz Modrzewski Krakow University, Krakow, Poland
}

\begin{abstract}
Introduction: Recently it has been shown that body image during sexual activities is a better predictor of the diversity of sexual experience than body image as a psychological trait. To measure contextual body image (as a state) the Body Exposure During Sexual Activity Questionnaire (BESAQ) was developed.

Material and methods: 845 women aged $18-55$ years were included in the study. The original model was first translated into Polish and consulted to create the version to be further validated. The original model was tested using confirmatory factor analysis (CFA). The population was divided in two equal groups - group 1 was used for exploratory factor analysis. Discriminant and convergent validity were checked. Sexual function was assessed by the Changes in Sexual Function Questionnaire.

Results: The Polish model of BESAQ (BESAQ-PL) consisted of 28 items with 2 lower-order factors. It had a satisfactory goodness of fit - comparative fit index $(\mathrm{CFI})=0.93$, Tucker-Lewis index $(\mathrm{TLI})=0.94$, root-meansquare error of approximation (RMSEA) $=0.06$ and $\chi^{2}=1360.0, d f=337, p<0.001$, excellent internal consistency measured by Cronbach's $\alpha=0.88$ and satisfactory discriminate validity. State body image (BESAQ-PL) did not predict sexual functioning. Face was the most important for self-consciousness during sexual contact in the population of Polish women.

Conclusions: State body image correlates with sexual functions but is not a major factor influencing sexual performance. Women in Poland are not anxious about body exposure during sexual activity. The BESAQ-PL may be used in the population of Polish women between 18 and 55 years of age.
\end{abstract}

Key words: body image, validation, sexual function, psychometric.

\section{Introduction}

Body image refers to the way of perceiving one's body physical appearance, general health and its physical, social and sexual functioning. It has cognitive, behavioral and emotional dimensions. Body image evolves and changes dynamically over time across the life span [1-3] and can be influenced by a variety of factors including spirituality and religious engagement [4], lifestyle factors [5], menstrual cycle phase [6], and physiological changes during menopausal transition [3], and it can influence perception of health and general/sexual well-being [2-6]. According to the current concept it is a fluid construct including not only subjective perception of physical appearance but also the ability to filter information, defining beauty in a broader context, sense of agency, belonging and empowerment rooted in adolescence [7] and mentoring other to like/dislike one's body [8].
Trait body image evaluation refers to one's general or typical feelings of satisfaction or dissatisfaction with various aspects of one's body. In contrast, contextual body image refers to how individuals perceive their body parts during specific situations such as sexual activities. Recently it has been shown that body image during sexual activities is a better predictor of sexual experiences than train body image. To be more precise, women who avoid exposing their bodies during sexual encounters are less satisfied with the relationship, more dissatisfied with their sexual function, less self-confident to refuse sex, less sexually assertive, have more difficulties in making a sexual decision and are less emotionally engaged in the romantic relationship [9]. Furthermore, it was found that body image mediates one's level of assertiveness, effective functioning during sex and sexual risk-taking behaviors (condomless sex) [10]. In that context, women who are dissatisfied with their bodies during sex tend to tell partner about their 
sexual expectations less frequently and less frequently experience arousal, orgasm and sexual satisfaction during sexual activities [9]. On the other hand, previous and current sexual experiences (having had genital or oral sex, being currently in a romantic relationship) or frequent sexual activities might positively influence body image and decrease anxiety/self-consciousness during sexual intimacy [11].

In modern societies social scripts force individuals, especially women, to meet a strict requirement of beauty. That "beauty" is believed to be essential in partner seeking. For women physical attractiveness is believed to be a sexual cue for male partners to engage in sexual relationship [12]. Because not everyone is be able to fulfill such "beauty ideals", body dissatisfaction might develop [11]. That may lead to avoidance of sexual body part exposure during intimate encounters with a sexual partner and further sexual dissatisfaction, distress and dysfunction. It is believed that body image as a state influences not only sexual life but also general well-being [11].

To measure contextual body image (as a state) the Body Exposure During Sexual Activity Questionnaire (BESAQ) was developed. This 28-items scale assesses the level of self-consciousness and avoidance to show body parts during sexual encounters. All question are rated from 0 - "never" to 4 - "always", where higher score reflects more anxious and avoidant behaviors [1].

As it has been shown that improving contextual body image by designed therapies or even repeated self-assessment of the body in daily life may improve sexual function within the relationship [9, 13], there is a need for validation and cultural adaptation of a scale assessing body image as BESAQ. It is especially important as up until now the scale has been validated only in the United Stated of America (USA) [1] and, partly, in Turkey [14].

This paper, to our best knowledge, is the first well-performed cultural adaptation and validation of BESAQ in Europe. We believe that the results of the original validation will be confirmed, giving a stronger basis for further validation in other European countries and, as a result, facilitating sexual therapy for couples with sexual dysfunctions. It has been shown that improving contextual body image by designed therapies or even repeated self-assessment of body in daily life may improve sexual functions within the relationship $[9,13]$.

The study aimed to: perform the linguistic validation of BESAQ-PL, investigate the psychometric properties of BESAQ-PL, assess the level of avoidance of body exposure during sexual activity in the population of Polish women aged 18-55 years old and factors affecting that body image, and evaluate which part of the female body (physical foci) are the most important for self-consciousness during sex.

\section{Material and methods}

\section{Sampling and recruitment}

1269 Polish Caucasian women with different socioeconomic backgrounds aged 18 to 55 years old were enrolled in this cross-section population-based study. The respondents were recruited between January 2016 and December 2017 both by online invitation posted in social media (Facebook, local portals) and in a gynecological outpatients' clinic in Katowice, during a routine yearly check-up visit. The questionnaire was available online as well as paper-pencil versions. Out of eligible respondents, 51 did not agree to participate in the study and 373 returned incomplete questionnaires. Finally, 845 were qualified for the analysis (282 with paper-pencil version and 563 online one). Out of that a sample of 75 women participated in the retest study and completed the questionnaire for the second time after 4 weeks. The response rate was $66.7 \%$. The minimal required sample size of 288 to perform confirmatory factorial analysis (CFA) was calculated using the Monte Carlo approach [15]. The mean age of the studied individuals was $34.4 \pm 10.8$ years and the body mass index ranged from 16.0 to $42.4(M=23.4, S D=3.5)$.

The inclusion criteria were age between 18 and 55 years and agreement for participation in the study.

Before being enrolled in the study all participants had to read the informed consent statement and agree to participate verbally (paper-pencil version) or by clicking "YES" in the case of the online questionnaire. All respondents were asked to fill out the questionnaire on day 0 and then in the period between 2 and 8 weeks later. To identify the subjects in the re-test procedure, all respondents were asked to enter an anonymous and unique identification code when completing the questionnaire the first time and after 2-8 weeks.

The study protocol was approved by the Ethical Committee of the Silesian Chamber of Physicians and Dentists in Katowice, Poland (ŚIL/KB/756p/15).

\section{Data collection}

The study was based on a questionnaire containing standard socioeconomical questions, medical history and sexual behaviors questions. All participants were asked to state their weight and height for BMI calculation.

The Hospital Anxiety and Depression Scale (HADS) was used for depressive symptoms and anxiety evaluation. Scores $<8$ were interpreted as lack of depressive symptoms/anxiety, 8-10 points as a borderline level for a depressive episode diagnosis/borderline anxiety, and $\geq 11$ points as a high risk of clinical depression episode/ high level of anxiety [16].

For female sexual dysfunction (FSD) the DMS-5 criteria [17] were used - the diagnosis was based on 
5 questions concerning presence of sexual problems and concomitant distress according to DSM-5 recommendations. Sexual activity was defined as any of the following: vaginal, anal and oral contacts, caressing/ cuddling, sexual foreplay, and masturbation.

Risky sexual behaviors (RSB) were defined as one of the following: sexual contacts with more than one sexual partner at the same time, getting engaged in sexual activity with a casual person (one-night stand), frequent change of sexual partners, having intercourse with a person living with HIV, inconsistent use of condoms in oral, anal and vaginal contacts, prostitution and using the services of an escort agency, sexual contacts under the influence of psychoactive substances other than alcohol and marihuana (chemsex) and drug injection with shared needles within the last 6 months [16].

Appearance Schemas Inventory-Revised (ASI-R) [18] was used for assessment of one's believes about the importance of physical appearance and owns body image cognition. This 20-items scale consists of two domains: self-evaluative salience and motivational salience. Total composite score is also calculated. Lower scores reflect dysfunctional investment's in one's appearance [18]. A Polish version of the scale is currently being developed.

The Polish version of the Body Esteem Scale (BES) [19] was used to assess body attitudes, namely physical self-concept. The scale consists of 35 items rating the degree of self-consciousness and satisfaction on a 5-point Likert scale. There are three domains of BES: sexual attractiveness, weight control and physical condition. Higher scores reflect more positive attitudes and higher level of self-consciousness and satisfaction.

The Body Areas Satisfaction Scale (BASS) and the Overweight Preoccupation Scale (OPS) from the Multidimensional Body-Self Relations Questionnaire (MBSRQ) [20] were used to assess satisfaction with discrete aspects of one's appearance, and fat anxiety, weight vigilance, dieting, and eating restraint, respectively.

For assessing sexual self-concept, the Sexual Self Schema Scale (SSSS) for women was used. The Polish version consists of 24 adjectives rated on a 7-point scale from 0 - "not at all descriptive of me" to 6 - "very much descriptive of me". The adjectives are grouped in four factors: factor 1 (romantic) including 8 items, factor 2 (passionate) -7 items, factor 3 (direct) - 4 items and factor 4 (embarrassed) - 5 items. Three positive factors (romantic, passionate and direct) constitute the positive schema, whereas the negative factor (embarrassed) constitutes the negative schema. Furthermore, four types of self-schemas were distinguished: positive schematic (high positive and low negative schema scores), negative schematic (high negative and low positive schema scores), co-schematic (both high scores) and aschematic (both low scores) [16].
Sexual problems were evaluated by the Changes in Sexual Function Questionnaire [16]. The scale consists of 14 questions assessing sexual experiences on a 5-point Likert scale. These 5-point scales include those concerning frequency of experiences (from never to everyday) or degree of enjoyment (from no pleasure to the greatest one). Sexual problems were identified if the respondent scored below 41 points (cut-off score $\leq 41$ ) for the total score and below 4, 6, 9, 12, and 11, for pleasure, desire/frequency, desire/interest, arousal/excitement, orgasm/completion, respectively. The scale has been used in a few studies in Poland and its validation is currently in progress [16].

In the first step a translation procedure of the original scale was introduced. The permission to use and translate the scale as well as the original version was obtained from Cash [21]. The linguistic validation was executed, according to the five-stage test adaptation procedure recommended by Beaton et al. [22]. The following steps were executed: forward translation, discrepancy resolution, backward translation, expert committee review, and pilot study.

The first step was performed independently by the trained, professional bilingual translator (uninformed) and the first author of this study (informed translator). It included the questionnaire instructions, items and the response options. When the two translations were being compared (discrepancy resolution) by the authors of this paper, some discrepancies were reported in items 14, 15, 26 and 28. In item 14 "articles of clothing" was translated as "parts of wardrobe", in item 15 "about my body" was translated as "about how my body looks", in item 26 "poses or positions" was translated as "positions" and in item 28 "in my partner's view" was translated as "in the presence of my partner". The back-translation was then performed by two independent bilingual translators for whom the first language was English. In the next step, a committee consisting of all three authors of this study, who are experienced in validation studies, reviewed the translation and finally obtained the BESAQ-PL No discrepancies were noted, and the preliminary version of BESAQ-PL was created. Finally, in the pilot study, the questionnaire was distributed among 25 female students from Medical School in Opole, Poland, in order to test its clarity, appropriateness, intelligibility and cultural relevance. Then students were interviewed to identify any difficulties in understanding or interpreting questions. The only discrepancy noted was in item 14 - after reviewing the results of pilot testing, the committee of experts decided to change "parts of wardrobe" to "parts of clothes" as it was better understood by the individuals. This final version of BESAQ-PL was prepared and used later for psychometric prosperities evaluation and cultural adaptation.

\section{Statistical analysis}

The Statistica 12.0 Pl computer software (StatSoft. Cracow, Poland), IBM SPSS 20 computer software with 
AMOS (IBM SPSS Statistics for Windows, Armonk, NY: IBM Corp; 2012) and R statistics (R project downloaded from: https://www.r-project.org/) were used for the statistical analyses. All the variables were verified for missing values (less than $5 \%$ ). In the case of CFA and exploratory factor analysis (EFA) cases with missing data were deleted. Univariate and multivariate distribution normality (skewness and kurtosis) was also checked. Values larger than 3 for skewness or larger than 10 for kurtosis were considered as indicative for non-normality. Multivariate distributions were evaluated using Mardia's coefficients (assessing multivariate kurtosis and skewness), with coefficients $\leq 5$ being indicative of normality [15]. The $p$ statistical significance level was set at 0.05 .

\section{Factor analysis}

As part of measurement invariances analysis factorial analysis was performed. In the first step CFA was used to analyze whether the existing model fit in the whole sample of 845 women using AMOS for IBM SPSS, version 25. Comparative fit index (CFI) and Tucker-Lewis index (TLI) $\geq 0.95$ and root-mean-square error of approximation (RMSEA) $\leq 0.06$ indicated an excellent model fit, whereas the levels between 0.80 and 0.95 and between 0.08 and 0.06 were indicative for acceptable fit, respectively [22]. Modification indices were inspected to identify non-fitting items. In the second step, the population was randomly divided into equal samples using SPSS software - group 1 and group 2. Sample 1 was used to perform EFA and sample 2 to perform CFA on the new model [15]. To be more specific, in group 1 Monte-Carlo parallel analysis was used to extract the optimal number of factors. As the data showed univariate normality but did not meet the criteria for multivariate normal distribution, the EFA using the principal axis with Varimax rotation analysis was performed. Items with factor loadings $\geq 0.40$ were inputted in the model [15]. Factorability was measured by inter-item correlations $(\geq 0.50)$, the KaiserMeyer-Olkin measure of sampling adequacy $(\geq 0.80$, and $=$ Bartlett's test of sphericity $p>0.05)$. When the new model was developed, CFA using maximum likelihood method with bootstrap for lack of multivariate normality was performed on group 2. Similarly to the initial analysis, modification indices were evaluated to obtain the best fit indices of the new model.

\section{Reliability}

Reliability was assessed by test-retest analysis using intraclass correlation coefficient (ICC) [22] and Cronbach's $\alpha$ coefficient for internal consistency analysis [22]. The ICC values of $>0.40$ reflected poor to fair agreement, 0.41-0.60 moderate agreement, 0.61-0.80 good agreement, and $>0.80$ excellent agreement between the two measurements. Cronbach's $\alpha$ values $>0.70$ were interpreted as adequate to excellent reliability.

\section{Construct validity}

Convergent and discriminant validity of the BESAQ-PL was assessed by correlations with other variables which measure proximal and distal constructs using Pearson's $r$. The $r$ value $\geq 0.10$ was indicative for a small, $r \geq 0.30-$ medium and $r \geq 0.50$ a large effect size [22].

\section{Hypotheses}

Based on the previous papers [21] it was hypothesized that:

1. Hypothesis one: BESAQ-PL will be negatively correlated with sexual function (Changes in Sexual Function Questionnaire - CSFQ), body area satisfaction scale from MBSRQ and with BES, and positively correlated with $B M I$, overweight preoccupation scale from the MBSRQ and appearance investment from the ASI-R.

2. Hypothesis two: The positive SSSS scores will be negatively correlated with BESAQ-PL scores.

3. Hypothesis three: Age, state body image (BESAQ scores), appearance investment (ASI-R), sexual self-schema (SSSS) but not trait body image (BES, MBSRQ) will predict sexual function (assessed by CSFQ).

4. Hypothesis four: some physical foci - breasts, waist, hips, buttocks and thigh (questions 61-69 from MBSRQ and BES) - will be of more concern for self-consciousness during sexual activity compared to other body parts.

\section{Results}

The basic characteristics of the investigated population with group 1 and group 2 comparison is presented in Table 1. The was no statistically significant differences between groups.

\section{Factorial analysis}

The Kaiser-Meyer-Olkin (KMO) measure confirmed the sampling adequacy for the analysis. The $\mathrm{KMO}=0.97$ and Bartlett's test of sphericity, $\chi^{2}=17254.8 . p<0.0001$ indicated a satisfactory correlation between items. Firstly, the original model was evaluated by CFA with analysis of modification indices, showing unsatisfactory results: $\mathrm{CFI}=$ $0.79, \mathrm{TLI}=0.77$, and RMSEA $=0.11$. As previously described, a Monte-Carlo analysis was performed on group 1 to establish the new model structure and then EFA was performed.

The analysis revealed two-factor structure of the scale accounting for $56.8 \%$ of variance. The first factor (BESAQ2 - nudity) included questions 3, 5, 7, 10, 11, 13, 24, 25, 28 
Table 1. Scores of BESAQ-PL and factors loadings

\begin{tabular}{|c|c|c|c|c|c|c|c|c|c|}
\hline \multirow[t]{2}{*}{ Question } & \multirow[t]{2}{*}{ Mean } & \multirow[t]{2}{*}{ Median } & \multirow[t]{2}{*}{ Min } & \multirow[t]{2}{*}{ Max } & \multirow[t]{2}{*}{ SD } & \multirow[t]{2}{*}{ Skewness } & \multirow[t]{2}{*}{ Kurtosis } & \multicolumn{2}{|c|}{ Factor loading } \\
\hline & & & & & & & & BEASQ1 & BESAQ2 \\
\hline Q1 & 1.34 & 1.00 & 0.00 & 4.00 & 1.06 & 0.38 & -0.53 & 0.73 & -0.17 \\
\hline Q2 & 1.35 & 1.00 & 0.00 & 4.00 & 1.10 & 0.35 & -0.75 & 0.77 & -0.24 \\
\hline Q3 & 2.05 & 2.00 & 0.00 & 4.00 & 1.34 & -0.01 & -1.19 & -0.08 & 0.48 \\
\hline Q4 & 1.26 & 1.00 & 0.00 & 4.00 & 1.12 & 0.55 & -0.54 & 0.71 & -0.19 \\
\hline Q5 & 2.76 & 3.00 & 0.00 & 4.00 & 1.18 & -0.66 & -0.49 & -0.32 & 0.71 \\
\hline Q6 & 1.24 & 1.00 & 0.00 & 4.00 & 1.19 & 0.65 & -0.48 & 0.66 & -0.38 \\
\hline Q7 & 2.33 & 2.00 & 0.00 & 4.00 & 1.29 & -0.19 & -1.08 & -0.17 & 0.71 \\
\hline Q8 & 1.00 & 1.00 & 0.00 & 4.00 & 1.10 & 0.79 & -0.42 & 0.80 & -0.24 \\
\hline Q9 & 0.91 & 0.00 & 0.00 & 4.00 & 1.10 & 0.94 & -0.17 & 0.70 & -0.14 \\
\hline Q10 & 2.69 & 3.00 & 0.00 & 4.00 & 1.39 & -0.68 & -0.85 & -0.08 & 0.69 \\
\hline Q11 & 2.46 & 3.00 & 0.00 & 4.00 & 1.15 & -0.42 & -0.60 & -0.28 & 0.67 \\
\hline Q12 & 1.07 & 1.00 & 0.00 & 4.00 & 1.18 & 0.80 & -0.49 & 0.64 & -0.40 \\
\hline Q13 & 2.99 & 3.00 & 0.00 & 4.00 & 1.05 & -0.91 & 0.15 & -0.12 & 0.69 \\
\hline Q14 & 1.40 & 1.00 & 0.00 & 4.00 & 1.19 & 0.42 & -0.78 & 0.56 & -0.18 \\
\hline Q15 & 1.17 & 1.00 & 0.00 & 4.00 & 1.10 & 0.61 & -0.60 & 0.82 & -0.28 \\
\hline Q16 & 1.20 & 1.00 & 0.00 & 4.00 & 1.12 & 0.56 & -0.64 & 0.73 & -0.12 \\
\hline Q17 & 1.10 & 1.00 & 0.00 & 4.00 & 1.11 & 0.73 & -0.28 & 0.81 & -0.25 \\
\hline Q18 & 1.17 & 1.00 & 0.00 & 4.00 & 1.10 & 0.61 & -0.45 & 0.84 & -0.23 \\
\hline Q19 & 1.11 & 1.00 & 0.00 & 4.00 & 1.11 & 0.72 & -0.36 & 0.80 & -0.28 \\
\hline Q20 & 1.16 & 1.00 & 0.00 & 4.00 & 1.12 & 0.64 & -0.54 & 0.84 & -0.20 \\
\hline Q21 & 0.99 & 1.00 & 0.00 & 4.00 & 1.12 & 0.87 & -0.20 & 0.72 & -0.20 \\
\hline Q22 & 0.91 & 1.00 & 0.00 & 4.00 & 1.07 & 0.92 & -0.07 & 0.74 & -0.24 \\
\hline Q23 & 1.33 & 1.00 & 0.00 & 4.00 & 1.25 & 0.52 & -0.85 & 0.67 & -0.35 \\
\hline Q24 & 2.58 & 3.00 & 0.00 & 4.00 & 1.21 & -0.43 & -0.84 & -0.28 & 0.74 \\
\hline Q25 & 2.63 & 3.00 & 0.00 & 4.00 & 1.16 & -0.50 & -0.63 & -0.34 & 0.73 \\
\hline Q26 & 1.16 & 1.00 & 0.00 & 4.00 & 1.15 & 0.50 & -0.96 & 0.70 & -0.17 \\
\hline Q27 & 1.09 & 1.00 & 0.00 & 4.00 & 1.09 & 0.67 & -0.51 & 0.82 & -0.17 \\
\hline Q28 & 2.55 & 3.00 & 0.00 & 4.00 & 1.33 & -0.44 & -1.00 & -0.27 & 0.74 \\
\hline BESAQ1 & 21.96 & 19.00 & 0.00 & 76.00 & 16.54 & 0.55 & -0.50 & & \\
\hline BESAQ2 & 23.04 & 24.00 & 0.00 & 36.00 & 7.98 & -0.37 & -0.37 & & \\
\hline BESAQ-PL & 1.25 & 1.18 & 0.00 & 4.00 & 0.79 & 0.41 & -0.47 & & \\
\hline
\end{tabular}

BESAQ - Body Exposure During Sexual Activity Questionnaire, BESAQ2 - nudity subscale, BESAQ1 - sexual activity subscale, Q - question. Factors for each subscale are bolded

(all were reverse coded in the original version). The second factor (BESAQ1 - sexual activity) included the rest of the questions. The factorability assessment revealed $\mathrm{KMO}=0.97$, Bartlett's test of sphericity, $\chi^{2}=9115.9$ $(d f-378), p<0.0001$. Factors loadings for each question are presented in Table 1. After establishing factorial structure of the model CFA was performed in group 2 . The analysis of modification indices revealed some degree of intercorrelation between factors. These correlations were included in the model to improve its fit (Fig. 1). $\chi^{2}=840.37$ $(d f-377)$ and RMSEA $=0.06$ showed an excellent fit, whereas $\mathrm{CFI}=0.94, \mathrm{TLI}=0.93$ were acceptable. In the final step CFA was performed on the entire sample with the following indices: $\chi^{2}=136.07(d f-337), C F I=0.94$,
$\mathrm{TLI}=0.93$, RMSEA $=0.06$, showing excellent to acceptable fit (Fig. 2).

Finally, in order to keep the original scale scoring the formula for calculation of BESAQ score was introduced, namely:

$$
(B E S A Q 1-B E S A Q 2+36) / 28
$$

The BESAQ-PL is available in the Appendix 1.

\section{Reliability}

BESAQ-PL revealed an excellent internal consistency measured by Cronbach's $\alpha-0.83$ for total score, 0.88 for BESAQ2 - nudity subscale and 0.96 for BESAQ1 - 


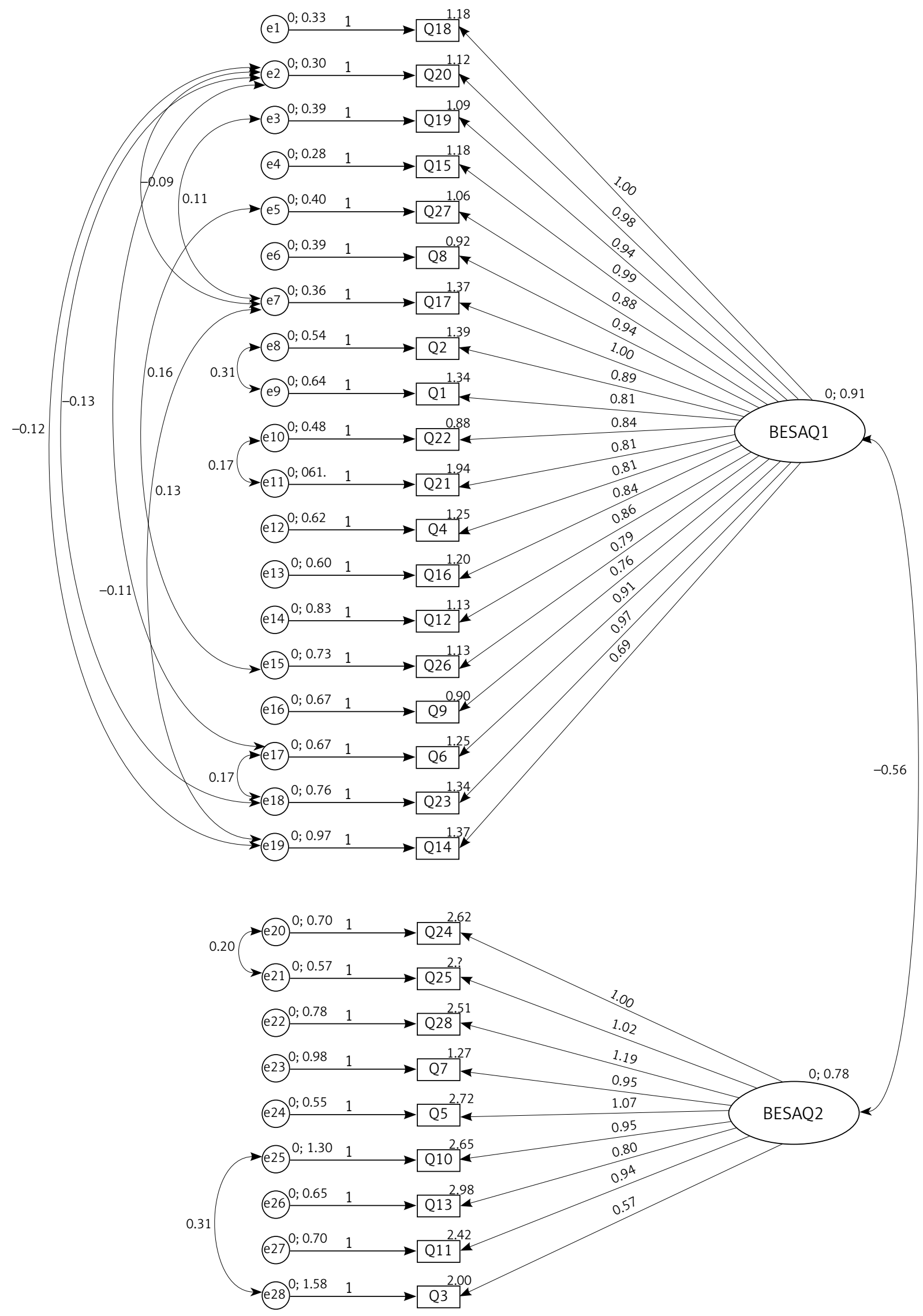

Fig. 1. Model analysis in group 2 


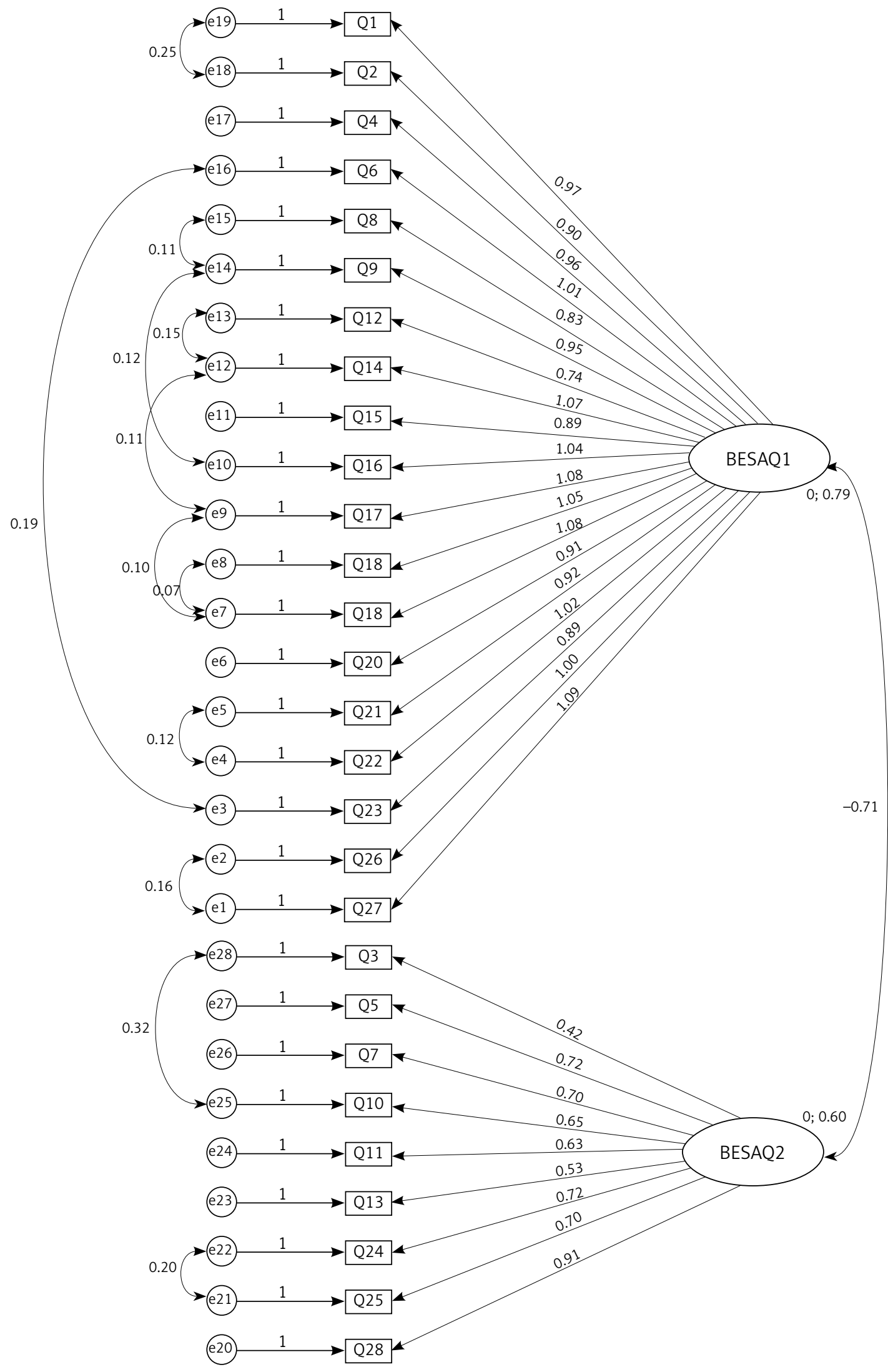

Fig. 2. Model analysis in entire sample 
sexual activity subscale. Similarly, the ICC was 0.88 (Cl: 0.84-0.92), showing excellent agreement between the two measurements.

\section{Construct validity and hypotheses}

The analysis of BESAQ correlations revealed, as hypothesized, a small to medium negative correlation between BESAQ-PL and CSFQ (except desire/interest domain), BASS investment in one's appearance, BES as well as a positive correlation between BESAQ-P, OPS and BMI (Table 2). Greater anxiety and body exposure avoidance during sexual activate were associated with lower body weight satisfaction, less positive body esteem, lower level of pleasure, arousal, orgasm and desire frequency, more dysfunctional investment in one's appearance, more overweight preoccupation and higher BMI.

The second hypothesis was also confirmed. A small to medium correlation between total SSSS score and

Table 2. Correlation analysis for BESAQ scores

\begin{tabular}{|c|c|}
\hline Variable & $\begin{array}{c}\text { Pearson's } r \\
(n=845)\end{array}$ \\
\hline Age & $0.13^{* * *}$ \\
\hline \multicolumn{2}{|l|}{ Trait body image } \\
\hline MBSRQ - body area satisfaction scale & $-0.47^{* *}$ \\
\hline $\begin{array}{l}\text { MBSRQ - overweight preoccupation } \\
\text { scale }\end{array}$ & $0.28^{* \star *}$ \\
\hline ASI-R total & $0.08^{*}$ \\
\hline BES - sexual attractiveness & $-0.47^{* *}$ \\
\hline BES - weight control & $-0.44^{* *}$ \\
\hline BES - physical condition & $-0.38^{* *}$ \\
\hline BMI & $0.33^{* * *}$ \\
\hline \multicolumn{2}{|l|}{ Sexual function } \\
\hline CSFQ-F - pleasure & $-0.32^{\star * \star}$ \\
\hline CSFQ-F - desire/frequency & $-0.22^{\star \star \star}$ \\
\hline CSFQ-F-desire/interest & -0.03 \\
\hline CSFQ-F - arousal/excitement & $-0.28^{* \star *}$ \\
\hline CSFQ-F - orgasm/completion & $-0.34^{* \star *}$ \\
\hline \multicolumn{2}{|l|}{ Sexual Self Schema } \\
\hline SSSS - romantic & $-0.25^{* \star \star}$ \\
\hline SSSS - passionate & $-0.17^{\star \star \star}$ \\
\hline SSSS - direct & $-0.19^{\star \star \star}$ \\
\hline SSSS - embarrasses & $0.36^{\star \star \star}$ \\
\hline SSSS total & $-0.37^{* \star \star}$ \\
\hline SSSS - positive schematic & $-0.05^{* \star *}$ \\
\hline SSSS - negative schematic & $0.37^{\star \star \star}$ \\
\hline
\end{tabular}

BAS - Body Esteem Scale, ASI-R - Appearance Schemas InventoryRevised, MBSRQ - Multidimensional Body-Self Relations Questionnaire; SSSS - Sexual Self Schema Scale, CSFQ - Changes in Sexual Function Questionnaire, ${ }^{*} p<0.05,{ }^{* *} p<0.001,{ }^{* * *} p<0.0001$
BESAQ as well as between positive schematic, negative schematic, SSSS subscales and BESAQ-PL was noted (Table 2). Negative schematic and embarrassed-schema women tended to have more anxious and avoiding body focus during sexual activity.

To examine the third hypothesis correlation coefficients between sexual function (CSFQ) and body image were calculated. The analysis revealed a small correlation between both trait and state body image measurements. The highest correlation was observed between CSFQ and having a romantic relationship (Table 3). Age did not correlate with sexual function. Similarly, a multiple forward linear regression analysis was performed. All variables that were significant in univariate analysis were included in the final model. The results

Table 3. Correlation analysis of sexual performance (CSFQ)

\begin{tabular}{|c|c|}
\hline Variable & $\begin{array}{c}\text { Pearson's } r \\
(n=845)\end{array}$ \\
\hline Age & -0.06 \\
\hline Religiosity (5-point Likert scale) & -0.08 \\
\hline Being in current relationship (YES) & $0.10^{*}$ \\
\hline Romantic relationship (5-point Likert scale) & $0.51^{\star *}$ \\
\hline Number of life-time sexual partners & $0.19^{\star *}$ \\
\hline RSB & -0.06 \\
\hline HADS - anxiety (YES) & $-0.14^{* *}$ \\
\hline HADS - depression (YES) & $-0.24^{\star *}$ \\
\hline \multicolumn{2}{|l|}{ State body image } \\
\hline BESAQ-PL & $-0.23^{\star *}$ \\
\hline \multicolumn{2}{|l|}{ Train body image } \\
\hline MBSRQ - body area satisfaction scale & $0.24^{\star \star}$ \\
\hline MBSRQ - overweight preoccupation scale & 0.02 \\
\hline BES - sexual attractiveness & $0.39^{* *}$ \\
\hline BES - weight control & $-24^{* *}$ \\
\hline BES - physical condition & $0.21^{* \star}$ \\
\hline ASI-R - self-evaluative salience & 0.07 \\
\hline ASI-R - motivational salience & $0.22^{* \star}$ \\
\hline ASI-R - total score & $0.14^{\star *}$ \\
\hline BMI & $-0.11^{*}$ \\
\hline \multicolumn{2}{|l|}{ Sexual Self Schema } \\
\hline SSSS - romantic & $0.12^{*}$ \\
\hline SSSS - passionate & $0.15^{*}$ \\
\hline SSSS - direct & $0.22^{* *}$ \\
\hline SSSS - embarrasses & $-0.10^{\star *}$ \\
\hline SSSS total & $0.21^{\star *}$ \\
\hline SSSS - positive schematic & $0.20^{* \star *}$ \\
\hline SSSS - negative schematic & $-0.10^{*}$ \\
\hline
\end{tabular}

BES - Body Esteem Scale, ASI-R - Appearance Schemas Inventory-Revised, MBSRQ - Multidimensional Body-Self Relations Questionnaire, SSSS Sexual Self Schema Scale, HADS - Hospital Anxiety and Depression Scale, CSFQ - Changes in Sexual Function Questionnaire, ${ }^{*} p<0.01,{ }^{* *} p<0.001$, *** $p<0.0001$ 
Table 4. Physical foci of self-consciousness during sexual activity in women based on BES and MBSRQ

\begin{tabular}{ll}
\hline Body parts & Mean score \\
\hline Eyes & 4.21 \\
\hline Lips & 3.92 \\
\hline Hair & 3.91 \\
\hline Cheeks & 3.81 \\
\hline Height & 3.79 \\
\hline Breasts & 3.73 \\
\hline Smell & 3.70 \\
\hline Face & 3.64 \\
\hline Genitalia & 3.62 \\
\hline General appearance & 3.61 \\
\hline Buttocks & 3.48 \\
\hline Feet & 3.47 \\
\hline Shoulders & 3.43 \\
\hline Hips & 3.40 \\
\hline Legs & 3.33 \\
\hline Waist & 3.30 \\
\hline Nose & 3.29 \\
\hline Ears & 3.26 \\
\hline Weight & 3.17 \\
\hline Thighs & 2.87 \\
\hline Belly & 2.87 \\
\hline BES-Body Ester
\end{tabular}

BES - Body Esteem Scale, MBSRQ - Multidimensional Body-Self Relations Questionnaire

showed that age $(\beta=0.12)$, duration of the relationship $(\beta=-0.18)$, having a romantic relationship $(\beta=0.33)$, level of sexual attractiveness (BES - sexual attractiveness; $\beta=0.13$ ), importance of looking sexually attractive (ASI-R - motivation salience; $\beta=0.29$ ), number of sexual partners $(\beta=0.11)$, and negative schema $(\beta=0.15)$ predicted sexual function (CSFQ scores). The model was satisfactory $-R^{2}=0.31, F(7,423)=28.1, p=0.001$. Older women, those in a romantic relationship, with a higher number of lifetime sexual partners, motivated highly to look more sexually attractive, feeling more sexually attractive, and more negative schematic had better sexual function. Surprisingly, state body image (BESAQ-PL) did not predict sexual functioning. The hypothesis was rejected.

The analysis of body parts self-consciousness (with higher scores reflecting more intense self-consciousness) revealed that eyes, lips, hair, cheeks and height had the highest scores (Table 4). Surprisingly, face parts were the most rated.

\section{Discussion}

Our study is the first validation of BESAQ performed on a non-USA sample of adult, non-college women.
We showed that the Polish 28-item version of BESAQ (BESAQ-PL) has good psychometric properties and can be used in a non-clinical sample of Polish women. It must also be underlined that the present study has some major clinical implications. Although state body image measured with BESAQ-PL did not prove to have a major impact on sexual performance, the evaluation of body image should be incorporated in everyday clinical practice. Other studies have shown that self-conscious and avoidant women are unable to communicate their needs, be assertive, relax and concentrate on feeling self-pleasure and/or pleasuring the partner $[23,24]$. For that reason, it is especially important for reproductive health care providers all over the world to assess and discuss in the appropriate manner all issues related to body image in women seeking help in their offices. The Polish adaptation of BESAQ will facilitate this goal. Finally, the study might serve as inspiration for others to validate the questionnaire and include body image evaluation in everyday clinical practice.

BESAQ was designed to measure the extent to which individuals are self-confident or avoidant/anxious while exposing their bodies during sexual activities. The scale has been used in a few studies on patients with provoked vestibulodynia $[2,25]$, anxiety during pelvic gynecological examination [26], pelvic organ prolapse plastic surgery, and also clitoral size in orgasmic/anorgasmic women, plastic abdomen surgery, level of shyness, body image in partners after limb amputation, cosmetic rhinoplasty [27], risky sexual behaviors (condomless sex) [10] and pregnancy/postpartum [28].

Body image esteem has been proven to be associated with sexual performances. Both young and older adults with low body self-consciousness reported higher sexual satisfaction and higher sexual function [27]. The potential mechanism might be explained by body appearance cognitive distraction - the induction of sexual distress by disturbing thoughts about negative self-perception of one's body $[29,30]$. Those thoughts will drive the attention from the sexual pleasure during sexual acts to sexual anxiety, leading to dissatisfaction and, in some cases, sexual avoidance or sexual dysfunction. More precisely, the more a woman is concentrated on how her body parts look (including genitalia), the higher is the risk of sexual concerns and lack of satisfaction [31, 32]. However, our study only partially confirms these observations - state body image did not predict sexual performance. There are a few possible explanations. Firstly, in the original analysis only state and trait body image, age, BMI and sexual self-schema score were included in the model. None of the other possible factors [16] were incorporated. Secondly, it might be speculated that other factors than state body image might have a greater impact on sexual performance $[16,23,24]$. Thirdly, some cultural difference cannot be excluded [31]. That needs further investigation. 
The results of our studies, as expected, confirmed the hypothesis similarly to that in the original validation study [21]. Interestingly, body image declined with age, which might be explained by more body self-consciousness and anxiety in older individuals [3]. Surprisingly, face appeared to have a greater importance compared to the USA sample. That might be caused by cultural variances [16] and a more differentiated study sample including a non-college sample of women (a difference between college individuals and older adults has been previously reported) [11].

The performed factor analysis revealed excellent model fit for the 28-item version of BESAQ-PL. Although to adjust the scoring method to the original scale a calculation formula had to be introduced, it did not change the meaning of the scale or its significance. As Turkish validation did not include factor analysis (showing only that 4 out of 28 items had significant factor loadings) or discriminant analysis [15]; the comparison with other papers is problematic.

The mean BESAQ-PL score was 1.25 (median = 1.17). Similar results were reported for a USA sample (1.12) [21], as well as in other studies - from 1.1 in women with provoked vestibulodynia [25] and healthy orgasmic women [27] to 2.03 in a sample of the postpartum women [29].

The analysis of papers using BESAQ showed internal consistency of the BESAQ from $\alpha=0.80$ in the Turkish study [14] to $\alpha=0.97$ in Boyer and Pukall [26]. Additionally, $\alpha$ of 0.96 has been reported for the online version and 0.96 for paper-and-pencil in Yamamiya et al. study [9]. The Cronbach's $\alpha$ for BESAQ-PL was 0.83 (0.84 for on-line version), showing excellent reliability.

The present study also has some limitations. Firstly, we did not include LBTQ women (lesbian, bisexual, transgender and queer) in the study protocol; it was shown that lesbian women had lower body dissatisfaction compared to heterosexual ones [33]. Secondly, the correlation between BESAQ and personality traits was also not assessed - recent studies showed that body image is associated with conscientiousness and neuroticism [34]. However, that correlation is more likely to be related with trait than state body image. Finally, further analysis on different age groups and a more heterogenous sample should be performed. However, despite that limitation the results of the study have a major clinical impact and provide a basis for further analysis.

\section{Conclusions}

State body image correlates with sexual functions but is not a major factor influencing sexual performance. Face as a part of the female body is the most important for self-consciousness during sexual contact. Women in Poland are not anxious about body exposure during sexual activity. The Polish version of the BESAQ has a good psychometric property and may be used in the population of Polish women between 18 and 55 years of age.

\section{Disclosure}

The authors report no conflict of interest.

\section{References}

1. Thompson JK, Schaefer LM. Thomas F. Cash: A multidimensional innovator in the measurement of body image. Some lessons learned and some lessons for the future of the field. Body Image 2019; 31: 198-203.

2. Maillé DL, Bergeron S, Lambert B. Body Image in Women with Primary and Secondary Provoked Vestibulodynia: A Controlled Study. J Sex Med 2015; 12: 505-515.

3. Chang SR, Yang CF, Chen KH. Relationships between body image, sexual dysfunction, and health-related quality of life among middle-aged women: A cross-sectional study. Maturitas 2019; 126: 45-50.

4. Tiggemann M, Hage K. Religion and spirituality: Pathways to positive body image. Body Image 2019; 28: 135-141.

5. Gattario KH, Frisén A. From negative to positive body image: Men's and women's journeys from early adolescence to emerging adulthood. Body Image 2019; 28: 53-65.

6. Kaczmarek M, Durda M. Variation in the body image perceptions of adolescent females and males and underlying social and cultural setting. In: Health and Quality of Life in Adolescence. Part I. Physical Health and Subjective Well-Being. Kaczmarek M (ed.). Bogucki Wydawnictwo Naukowe, Poznań 2011: 225-243.

7. Kaczmarek M, Trambacz-Oleszak S. The association between menstrual cycle characteristics and perceived body image: a cross-sectional survey of Polish female adolescents. J Biosoc Sci 2016; 48: 374-390.

8. Tiggemann M, Barbato I. "You look great!": The effect of viewing appearance-related Instagram comments on women's body image. Body Image 2018; 27, 61-66.

9. Yamamiya Y, Cash TF, Thompson JK. Sexual experiences among college women: The differential effects of general versus contextual body images on sexuality. Sex Roles 2006; 55: 421-427.

10. Blashill AJ, Safren SA. Body dissatisfaction and condom use self-efficacy: A meta-analysis. Body Image 2015; 12: 73-77.

11. Gillen $\mathrm{MM}$, Markey $\mathrm{CH}$. A review of research linking body image and sexual well-being. Body Image 2019; 31: 294-301.

12. Woertman L, van den Brink F. Body Image and Female Sexual Functioning and Behavior: A Review. J Sex Res 2012; 49: 184-211.

13. Fuller-Tyszkiewicz M. Body image states in everyday life: Evidence from ecological momentary assessment methodology. Body Image 2019; 31 : 245-272.

14. Dinc H, Beji NK. Cultural Adaptation, Internal Consistency and TestRetest Reliability of the Turkish Version of the Body Exposure during Sexual Activities Questionnaire. Int J Caring Sci 2017; 10: 1178-1186.

15. Swami V, Barron D. Translation and validation of body image instruments: Challenges, good practice guidelines, and reporting recommendations for test adaptation. Body Image 2019; 31: 204-220.

16. Nowosielski K, Jankowski KS, Kowalczyk R, et al. Sexual Self-Schema Scale for Women - Validation and Psychometric Properties of the Polish Version. Sex Med 2018; 6: 131-142.

17. American Psychiatric Association. Diagnostic and Statistical Manual of Mental Disorders (DSM-5®). $5^{\text {th }}$ ed. American Psychiatric Publishing, Arlington (VA) 2013.

18. Cash TF. Brief manual for the Appearance Schemas Inventory-Revised. 2003. Available from the author at www.body-images.com.

19. Lipowska M, Lipowski M. Polish normalization of the body esteem scale. Health Psychol Rep 2013; 1: 72-81.

20. Brytek-Matera A, Rogoza R. Validation of the Polish version of the Multidimensional Body-Self Relations Questionnaire among women. Eat Weight Disord St 2014; 20: 109-117. 
21. Cash TF, Maikkula CLM, Yamamiya YY. "Baring the Body in the Bedroom": Body Image, Sexual Self-Schemas, and Sexual Functioning among College Women and Men. Electronic Journal of Human Sexuality 2004; 7. http://www.ejhs.org/volume7/bodyimage.html 1

22. Beaton DE, Bombardier C, Guillemin F, Ferraz MB. Guidelines for the Process of Cross-Cultural Adaptation of Self-Report Measures. Spine 2000; 25: 3186-3191.

23. Basson R. The Female Sexual Response: A Different Model. J Sex Marital Ther 2000; 26: 51-65.

24. Lema VM, Lema APV. Body Image and Female Sexual Functioning: Impact on Health Service Delivery in a Developing Country Context. Investigations in Gynecology Research \& Womens Health (IGRWH) 2017; 1. doi: 10.31031/IGRWH.2017.01.000506

25. Sutton KS, Pukall CF, Chamberlain S. Pain, Psychosocial, Sexual, and Psychophysical Characteristics of Women with Primary vs. Secondary Provoked Vestibulodynia. J Sex Med 2009; 6: 205-214.

26. Boyer SC, Pukall CF. Pelvic Examination Experiences in Women With and Without Chronic Pain During Intercourse. J Sex Med 2014; 11 : 3035-3050.

27. Randall A. Shyness, Love-Shyness, and Individual Differences in Sexual Attitudes and Behaviors. Honors Thesis Collection; 2016; 396. https:// repository.wellesley.edu/thesiscollection/396 (access: July 21, 2019).

28. Castellini G, Lo Sauro C, Ricca V, Rellini AH. Body Esteem as a Common Factor of a Tendency Toward Binge Eating and Sexual Dissatisfaction Among Women: The Role of Dissociation and Stress Response During Sex. J Sex Med 2017; 14: 1036-1045.

29. Serrano Drozdowskyj E, Gimeno Castro E, Trigo López E, et al. Factors Influencing Couples' Sexuality in the Puerperium: A Systematic Review. Sex Med Rev 2020; 8: 38-47.

30. Quinn-Nilas C, Benson L, Milhausen RR, et al. The Relationship Between Body Image and Domains of Sexual Functioning Among Heterosexual, Emerging Adult Women. Sex Med 2016; 4: e182-e189.

31. Oakley SH, Vaccaro CM, Crisp CC, et al. Clitoral Size and Location in Relation to Sexual Function Using Pelvic MRI. J Sex Med 2014; 11: 10131022.

32. Bolton MA, Pruzinsky T, Cash TF, Persing JA. Measuring Outcomes in Plastic Surgery: Body Image and Quality of Life in Abdominoplasty Patients. Plast Reconstr Surg 2003; 112: 619-625.

33. Alvy LM. Do lesbian women have a better body image? Comparisons with heterosexual women and model of lesbian-specific factors. Body Image 2013; 10: 524-534.

34. Allen MS, Walter EE. Personality and body image: A systematic review. Body Image 2016; 19: 79-88. 
Appendix 1. BESAQ-PL - Polish version of the Body Exposure during Sexual Activities Questionnaire

\section{Kwestionariusz Obrazu Ciała Podczas Aktywności Seksualnej - wersja polska BESAQ - The Body Exposure during Sexual Activities Questionnaire}

Poniżej znajduje się lista zdań dotyczących myśli i zachowań, których każdy może doświadczać podczas aktywności seksualnej. Proszę przeczytać poniższe stwierdzenia i zaznaczyć, jak często odnoszą się one do Twojej aktywności seksualnej. Proszę szczerze odnieść się do poniższych stwierdzeń, wstawiając liczbę od 0 do 4 po lewej stronie stwierdzenia, używając następującej skali:

\begin{tabular}{ccccc}
\hline Nigdy & Rzadko & Czasami & Często & $\begin{array}{c}\text { Prawie zawsze } \\
\text { lub zawsze }\end{array}$ \\
\hline 0 & 1 & 2 & 3 & 4 \\
\hline
\end{tabular}

UWAGA: aktywność seksualna może obejmować pieszczoty, grę wstępną, masturbację oraz stosunek ptciowy, który definiuje się jako penetrację (wejście do) partnera/partnerki.

1. Podczas aktywności seksualnej myślę, że mój partner może w moim wyglądzie zauważyć coś zniechęcającego.

2. Podczas seksu obawiam się, że moje ciało będzie dla partnera nieatrakcyjne.

3. Podczas aktywności seksualnej nie przejmuję się tym, jak wygląda moje ciało.

4. Podczas aktywności seksualnej coś w moim wyglądzie sprawia, że czuję się zahamowana.

5. Czuję się komfortowo, kiedy jestem rozbierana przez mojego partnera.

6. Podczas seksu wolę ukrywać moje ciało pod pościelą.

7. Czuję się komfortowo, kiedy podczas aktywności seksualnej mój partner patrzy na moje narządy płciowe.

8. Podczas seksu obawiam się, że mój partner uzna moje ciało za odpychające.

9. Podczas aktywności seksualnej obawiam się, że mój partner uzna rozmiar lub wygląd moich narządów płciowych za nieodpowiedni lub nieatrakcyjny.

10. Nie mam nic przeciwko temu, aby mój partner widział mnie nago.

11. Podczas aktywności seksualnej myślę, że moje ciało wygląda seksownie.

12. Nie lubię, kiedy podczas aktywności seksualnej mój partner widzi mnie całkowicie nago.

13. Oczekuję, że mój partner będzie podniecony, widząc mnie bez ubrań.

14. Podczas seksu wolę mieć na sobie niektóre części ubrania.

15. Czuję się skrępowana wyglądem mojego ciała podczas aktywności seksualnej.

16. Podczas seksu obawiam się, że mój partner uzna wygląd lub zapach moich narządów płciowych za odpychający.

17. Podczas aktywności seksualnej próbuję ukryć niektóre części mojego ciała.

18. Podczas aktywności seksualnej ciągle myślę, że niektóre części mojego ciała są zbyt nieatrakcyjne, aby mogły być seksowne.

19. Nie chcę, by podczas seksu partner widział niektóre części mojego ciała.

20. Podczas aktywności seksualnej boję się, co mój partner pomyśli o wyglądzie mojego ciała.

21. Podczas aktywności seksualnej obawiam się, że mój partner może stracić podniecenie przez odczucie, jakiego dozna, dotykając części mojego ciała.

22. Podczas aktywności seksualnej jest mi ciężko nie myśleć o mojej wadze.

23. Czuję się skrępowana, kiedy podczas seksu pokój jest za bardzo oświetlony.

24. Ogólnie czuję się dobrze, kiedy podczas aktywności seksualnej pokazuję części mojego ciała partnerowi.

25. Podczas seksu lubię, kiedy mój partner patrzy na moje ciało.

26. Podczas seksu unikam niektórych pozycji ze względu na to, jak moje ciało będzie wyglądało w oczach mojego partnera.

27. Podczas aktywności seksualnej rozpraszają mnie myśli o tym, jak wyglądają niektóre części mojego ciała.

28. Przed lub po seksie czuję się komfortowo, chodząc nago w obecności mojego partnera.

\section{Scoring:}

BESAQ1 - sexual activity domain: sum of scores for questions 1, 2, 4, 6, 8, 9, 12, 14-23, 26, 27

BESAQ2 - nudity domain: sum of scores for questions 3, 5, 7, 10, 11, 13, 24, 25, 28

To calculate BESAQ-PL score: (BESAQ1 - BESAQ2 + 36) / 28 